\title{
Contribution of Modern Biogas Plant to Energy Source and Environment Protection in Rwanda
}

Marie Judith Kundwa ${ }^{1 *}$, Constant Mahame ${ }^{1}$, Theoneste Bigirimana ${ }^{1}$ and Pascaline Sanga ${ }^{2}$,

${ }^{1}$ Department of Civil Engineering, Construction and Management, Lanzhou Jiaotong University, Lanzhou, P.R. China

${ }^{2}$ Departement of Environment Engineering, Lanzhou University of Technology, Lanzhou, P.R. China

\begin{abstract}
The government of Rwanda through its Ministry of Infrastructure (MININFRA), the authority in charge of energy has initiated different initiatives aimed at finding long term solutions to energy shortage in the country where no investment has been done the last 20 years in electricity generation. Among these solutions, biogas has been identified as one of the sector to be developed. Energy plays a major role in development process of every country. This research is conducted in order to handle energy shortage problems in secondary schools located in rural areas by using a modern biogas. To achieve the aims of this research, the field survey was conducted at G.S. Ntarama and data about numbers of students and teachers, type and amount of waste produced, and impacts of lack of electricity on education were collected through interviews and questionnaires. The data were analyzed and the size of digester was estimated to be $118.524 \mathrm{~m}^{3}$. In addition to reducing the emission of carbon dioxide to 7 times lesser than what is emitted by firewood, it was also found that the use of biogas proves to be economical by covering the cost of firewood consumed in one month to five months. The produced energy allocated both in lighting for 4 hours and cooking for 3 hours was proved to be more advantageous and cost effective. Use of modern biogas contribute to the quality of education, environmental protection, agriculture productivity, and improve the lives of Rwandan people in general.
\end{abstract}

Keywords: G.S. Ntarama secondary school; Architectural design of biogas; Energy source; Rural schools; Environment protection

Abbreviations: AD: Anaerobic Digestion; EWSA: Energy Water and Sanitation Authority; ESF: Ecological Sanitation Foundation; G.S: Groupe Scolaire; CITT: The Centre for Innovation and Technology Transfer; CAD: Computer Aided Design; D: Day; H:Hour; $\mathrm{H}_{2}:$ Hydrogen; HRT: Hydraulic Retention Time; PH: Percentage of Hydrogen; $\mathrm{H}_{2} \mathrm{~S}$ : Hydrogen Sulfide; $\mathrm{CO}_{2}$ : Carbon Dioxide; $\mathrm{CH}_{4}$ : Methane; $\mathrm{C} / \mathrm{N}$ : CarbonNitrogen Ratio; $\mathrm{CO}_{2}$ : Carbon Dioxide; KIST: Kigali Institute of Science and Technology; L: Liter; MININFRA: Ministre of Infrastructure; NPK: Nitrogène Phosphorous Potassium; PVC: Polyvinyle Chloride; Pcs: Pièces; Rwf: Rwanda Francs; R: Radius; RURA: Rwanda Utilities Regulatory Agency

\section{Introduction}

The Government of Rwanda is landlocked with few natural resource and minimal industry. It is increasing looking at alternative sources of energy to power the country given the energy deficit. Currently, only $5 \%$ of Rwanda's population has access to electricity, but the government has set the target of $16 \%$ by 2012 and $35 \%-40 \%$ in 2020 [1]. The production and collection of biogas from a biological process was documented for the first time in United Kingdom in 1895 [2]. Since then, the process was further developed and broadly applied for wastewater treatment and sludge stabilization. The energy crisis in the early 70's brought new awareness about the use of renewable fuels, including biogas. From AD, the interest in biogas has further increased. Renewable energy is one of the most important factors to global prosperity. The dependence on fossil fuel as primary energy source has led to global climate change, environmental degradation and human health problems [3]. Today due to global efforts of displacing the fossil fuels used for energy production and the necessity of finding environmentally sustainable solutions for the treatment and recycling of animal manure and organic wastes [4].

In Africa, especially in Ugandan country, a biogas plant or latrine when successful is an appropriate and sustainable method to deal with human or animal waste. Using biogas for cooking and lighting reduces the strain on the environment by decreasing the use of biomass and the production of greenhouse gases (as methane that is produced normally from manure is now captured and used). The biogas system also provides a barrier protecting ground water from contamination from untreated waste [5]. The utilization of energy in the form of biogas is one of the environmentally sound alternative renewable energy sources [6]

The biogas technology was launched in Rwanda at the end of 1990s in search of an alternative energy for cooking and lighting and as an environment conservation strategy. The Centre for Innovation and Technology Transfer (CITT) of Kigali Institute of Science and Technology (KIST) has played an important role as an innovator of the biogas systems in Rwanda but also as a contracting agency for constructing most of the larger units in the country [7]. As in India With the advancement in biogas technology over the years, many biogas reactor designs have been developed so far as a result of alteration in biomass as feed-stocks [8].

Energy can also contribute to the solution of problems particularly poverty, the situation of women, population growth, unplanned urbanization and excessively consumptive life styles [9] especially in rural areas people prefer to cook by cutting the trees. As known, traditional firewood cooking causes faster depletion of biomass resources and increases the time that women require in collecting firewood. These activities consume a great deal of the time and labor of women and increase the drudgery of women. In addition, the use of traditional energy technologies has a negative impact on women's health due to the smoke from firewood and their heavy workload. There is therefore the need for an intervention, that help to reduce women's labor and time, which could be used for other productive purposes, and to

${ }^{*}$ Corresponding author: Marie Judith Kundwa, Department of Civil Engineering Construction and Management, Lanzhou Jiaotong University, 88 West Anning Road, Lanzhou, P.R. China, Tel: +8618609491391; E-mail: kudith04@yahoo.fr

Received May 24, 2018; Accepted October 25, 2018; Published October 31, 2018

Citation: Kundwa MJ, Mahame C, Bigirimana T, Sanga P (2018) Contribution of Modern Biogas Plant to Energy Source and Environment Protection in Rwanda. J Civil Environ Eng 8: 325. doi: 10.4172/2165-784X.1000325

Copyright: ( 2018 Kundwa MJ, et al. This is an open-access article distributed under the terms of the Creative Commons Attribution License, which permits unrestricted use, distribution, and reproduction in any medium, provided the original author and source are credited. 
improve the health conditions of Women. In this regard, an intervention with anaerobic digestion is needed [10]. The modern uses of biomass take the advantages of modern biomass conversion technologies (combustion, pyrolysis, gasification, fermentation, anaerobic digestion) for production of heat and electricity, liquid and gaseous transportation fuel, biogas for cooking etc. [11].

Improving living standard, economic and industrial expansions, population growth has possess serious challenges on energy sector [12]. Education system in these days requires much more knowledge on ICT (Information, Communication and Technology), means that students need access to Computer lab and internet to develop their knowledge and skills in order to know what is happening all around in this world globalization. To review their study at evening, without electricity is likely to be impossible. Student at G.S. Ntarama are not exploring all of their potentiality due to this lack of electricity energy and their competitive weakened.

With respect to this research, it is significant to consider the amount of wastes produced at G.S. Ntarama in order to provide a modern biogas, to reduce the use of firewood for cooking and as an alternative energy for lighting in schools, thus saving money, improve their educational background and protect the environment at the same time, that is why I have selected this topic.

\section{Contribution of the research}

This research has been chosen because there are no other researches related to ecological sanitation system that has been conducted within the study area. Being among Cells of Gashaki (pilot sector of Musanze District), Mbwe Cell has been chosen in order to assess achievements related to equitable sanitation system for fulfilling the target of Rwanda vision 2020. Production of biogas through anaerobic digestion of animal manure and slurries as well as of a wide range of digestible organic wastes, converts these substrates into renewable energy and offers a natural fertilizer for agriculture That is why I consider that biogas plants will be more and more used in the future [13]. Additionally, results of this research will be used as a raw data for future research as well as providing information for planners in order to elaborate plans for implementation of equitable and efficient sanitation system to recycle and reuse of toilet waste in schools located in rural areas.

\section{Materials and Methods}

In order to attain the above objectives, the following methods have been taken into account in order to obtain perfect, updated and comprehensive result. Documentation from the library and internet was used in the transformation of human excreta into energy and nutrients for agriculture purpose. Data collection on number of students, teachers, people, and animals to estimate amount of organic waste produced which will help do estimate the volume of digester. Field survey about their education background without electricity. The Computer soft wares to design an effective and adequate modern biogas structure and ArcGIS was used to localize the Groupe scolaire de Ntarama in Musanze District.

This chapter describes a brief presentation of the site, data gathered, method, and techniques used to obtain data from field survey and observation in order to design a modern biogas plant at G.S. Ntarama in Gashaki Sector.

\section{Study area description}

G.S. Ntarama is co-education, is one among two G. S of Gashaki sector in Musanze District (Figures 1 and 2) with 2058 students and 37 teachers. It is located in Mbwe Cell one of four Gashaki Sector's Cells. It is located on the Eastern extremity of Mbwe cell Sector and it is bordered by Kanzo Village in the north and Kamato village in the Northeast, Budiho village in South, and Ngambi Village in its Western part. It was a primary school from 1929 to 2009 that serves children from primary 1 to primary 6 (ages 5 to 14). It became a Groupe Scolaire in 2009 grouped with nine years basic education to implement the policy of Rwanda of education for all.

\section{Musanze District}

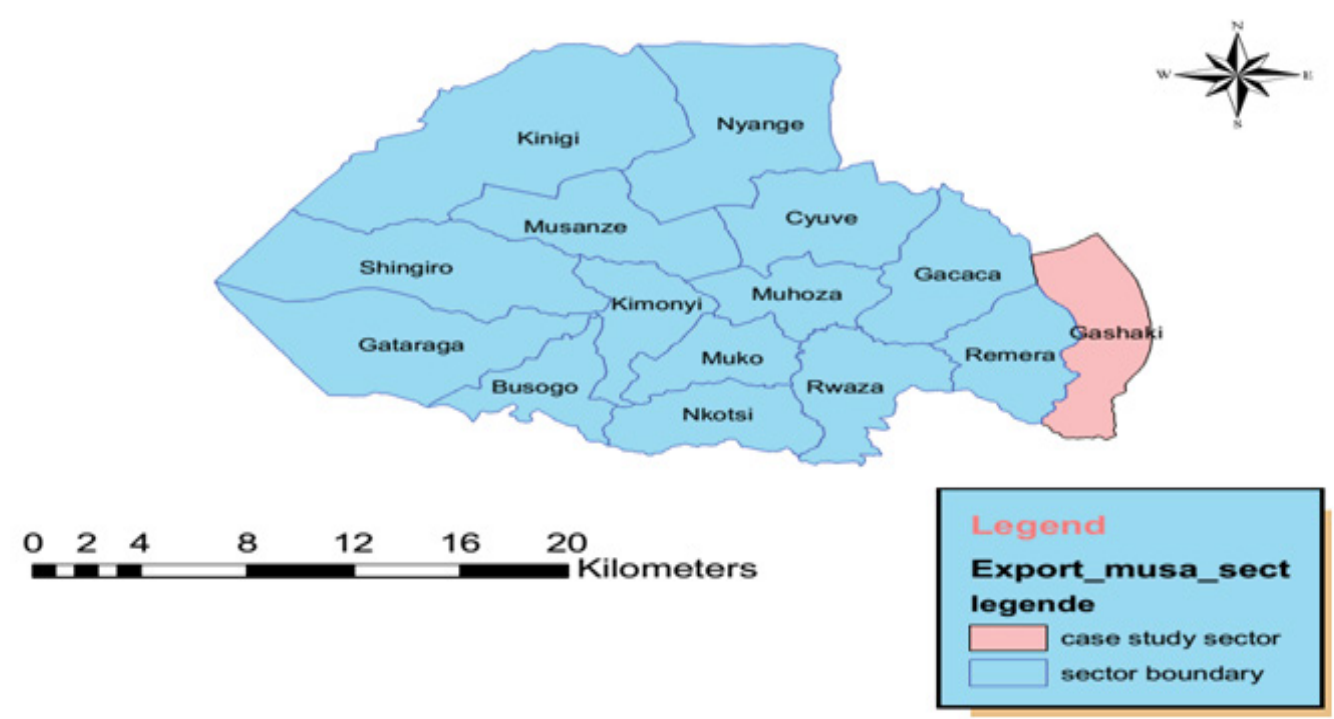

Figure 1: Location of Gashaki Sector in Musanze District. 


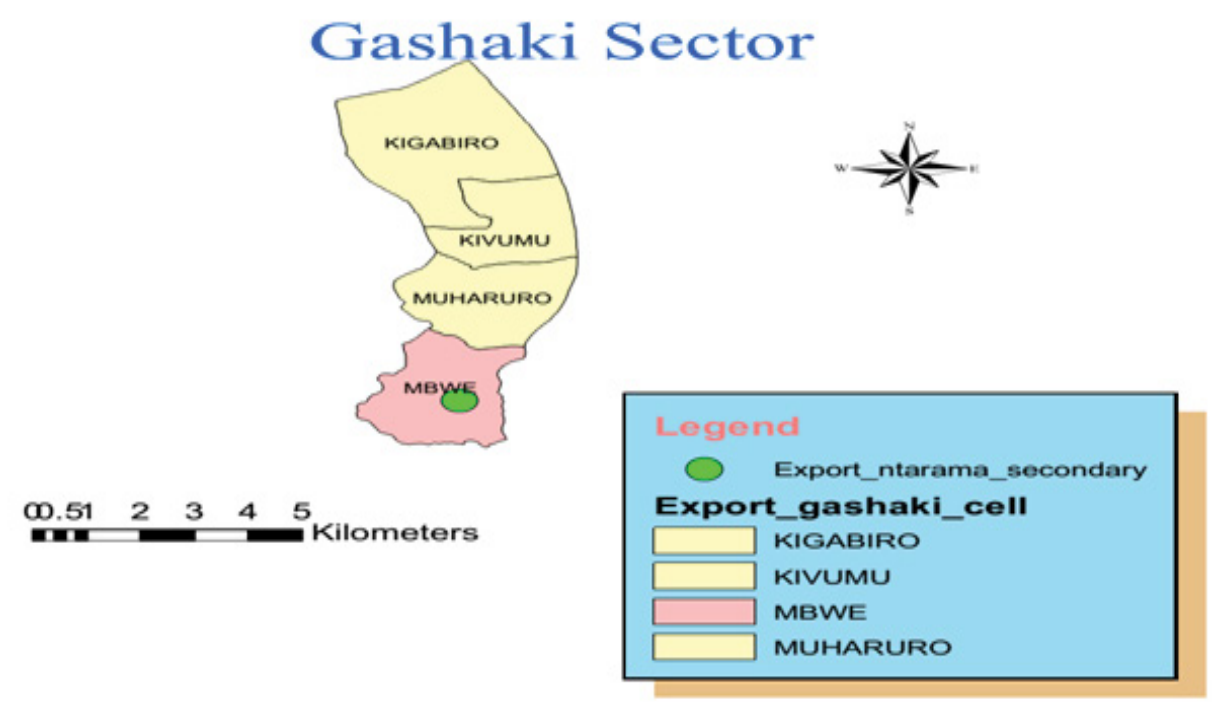

Figure 2: Location of G.S. Ntarama in Gashaki Sector.

\section{Data collection}

Problems of electrification: Electricity is a major factor indicator of development. Lack of electricity at G.S. Ntarama cause some problems related to quality of education which was at low level. A questionnaire was addressed to those students, teachers and headmaster by interviewing them about their education background without electricity. Most of them show that the today's education system requires information, communication and technology system. Those students do not have computer lab to develop their knowledge and different skills in order to know what happen around them to profit the world globalization. To review their study at evening, laboratory test without electricity is likely to be impossible. Student at G.S. Ntarama are not exploring all of their potentiality due to this lack of electricity energy and their competitive weakened as shown by the national exams more than $50 \%$ failed.

Feeding materials field survey: Assessment on the number of cows, rabbits, pigs, students and teachers at G.S. Ntarama was carried out to establish raw materials requirements for plant sustainability. Preliminary surveys to identify availability of water and location materials for construction and to assess the condition of proposed site. The number of students was averagely estimated at 1674 students and 22 teachers in primary, 384 students and 15 teachers in secondary. Secondary students and all teachers are those who will use biogas in lighting and cooking and they show the willingness of use biogas. The research was based on the interview, site visit, observation since the main requirement in this project is the analysis of organic waste production per day and number of community at G.S. Ntarama that will consume finally biogas product.

\section{Results and Discussion}

Planning of biogas plants in G.S. Ntarama is a project where different features are provided in order to achieve different objectives mentioned previously in this research. Each element is explained technically in this chapter. The main elements in the biogas design project are Reception tank, Digester or fermenter, Gas holder, Overflow tank.

\section{Location}

The site on which the biogas plant will be constructed around cattle manure and student latrines at G. S De Ntarama.

\section{Design components}

A complete biogas plant will have the gas generation sub-system (the digester), feed and slurry handling sub-system (the inlet and outlet of the slurry), gas distribution and utilization sub-system (the pipe work and terminal appliances).

The required quantity of dung and water is mixed in the inlet tank and this mix in the form of slurry is allowed to be digested inside the digester. The gas produced in the digester is collected in the dome, called as the gasholder. The digested slurry flows to the outlet tank from the dig through the manhole. The slurry then flows through overflow opening to the compost pit where it is collected and composted. The gas is supplied to the point of application through the pipeline.

Before deciding the size of plant, the dung was collected for several days to determine what the average daily dung production is. The amount of dung daily available helps in determining the capacity of the plant. The important point considered is that the size of plant was selected on basis of available dung and the community size because is toilet -linked biogas plant.

The plant is not underfed because the gas production will be low; in this case, the pressure of the gas might not be sufficient to displace the slurry in the outlet chamber.

\section{Quantity and properties of feeding materials}

The information gotten from the field survey, the following data are found:

- 384 students

- 37 teachers

- 2 cows

- 13 rabbits

The number of community that will consume biogas product in cooking and lighting are secondary students and all teachers (421 humans). Specific toilet water production per person per day is ca. 5 liters; expected biogas production is 40 liters per person per day [14] (Table 1). 


\section{Sizing of toilet-linked biogas plant}

Biogas demand vs. anticipated biogas yield: Biogas demand may be estimated by way of appliance consumption data and assumed periods of use, but this approach can only work to the extent that the appliances to be used are known in advance.

\section{Appliance consumption data and assumed periods of use.}

- Gas consumption of one flame is about 175 liters of biogas per hour [15],

- Gas consumption of the biogas lamp is 120 liters per hour [15],

- Operating hour of cooker will be from 8 AM-11AM. (Data gotten from field)

- The lamp shall be light from 6 AM to 7 AM and 6 PM to 9 PM. (Data gotten from field)

Number of appliance and committee that will consume produced biogas

- 4 flames for cooking

- 18 biogas lamps for lighting

- 421 persons (Data got from the field)

\section{Calculation}

\section{A) Gas production}

Estimate, biogas yield from 2 cows $\mathrm{Y}_{\mathrm{c}}$

$Y_{c}=250 \times 2=500 \mathrm{l} / \mathrm{d}$

Estimate, biogas yield from all 13 rabbit $\mathrm{Y}_{\mathrm{R}}$

$\mathrm{Y}_{\mathrm{r}}=200 \times 13=2600 \mathrm{l} / \mathrm{d}$

The specific biogas production from the co-digestion of toilet water is about 40 liters per person per day

Estimated biogas yield ( $\mathrm{Y}_{\mathrm{s}}$ ) from all 421 members

$\mathrm{Y}_{\mathrm{s}}=421 \times 40=16840 \mathrm{l} / \mathrm{d}$

Total biogas production $\left(\mathrm{Y}_{\mathrm{T}}\right)$ from the anaerobic treatment of cow, rabbit manure and toilet water are

$\mathrm{Y}_{\mathrm{T}}=500+2600+16840=19940 \mathrm{l} / \mathrm{d}$

\section{B) Biogas demand}

They will use 4 flames in 3 hours for cooking per day

Biogas demand for cooking (DC)

$\mathrm{D}_{\mathrm{C}}=175 \times 4 \times 3=2100 \mathrm{l} / \mathrm{d}$

The 18 biogas lamps will be lit for 4 hours per day

Biogas demand for lighting $\left(\mathrm{D}_{\mathrm{L}}\right)$

$\mathrm{D}_{\mathrm{L}}=120 \times 18 \times 4=8640 \mathrm{l} / \mathrm{d}$

Total biogas demand $\left(\mathrm{D}_{\mathrm{T}}\right)$ cooking and lighting is

$\mathrm{D}_{\mathrm{T}}=2100+8640=10740 \mathrm{l} / \mathrm{d}$

The anticipated biogas production $\left(\mathrm{Y}_{\mathrm{T}}\right)$ matches gas demand $\left(\mathrm{D}_{\mathrm{T}}\right)$

Sizing the gasholder: The required gasholder capacity, i.e., the gasholder volume $\left(\mathrm{V}_{\mathrm{G}}\right)$, is an important planning parameter and depends on the relative rates of biogas generation and gas consumption. If the gasholder capacity is insufficient, part of the gas produced will be lost. The remaining gas will not be sufficient to meet the demand. If the gasholder is made too large, construction costs will be unnecessarily high, but plant operation will be more convenient.

The gasholder must therefore be made large enough to:

- Cover the peak consumption rate $\left(\mathrm{V}_{\mathrm{g} 1}\right)$ and

- Hold the gas produced during the longest zero-consumption period $\left(\mathrm{V}_{\mathrm{g} 2}\right)$

- Furthermore, the gasholder must be able to compensate for daily fluctuation in gas production. These fluctuation ranges from $75 \%$ to $125 \%$ of calculable gas production.

Dairy gas yield is 19940 liters.

The hourly biogas production $\left(\mathrm{Y}_{\mathrm{M}}\right)$

$\mathrm{Y}_{\mathrm{M}}=19940 / 24=830.83 \mathrm{l} / \mathrm{h}$

Hence the maximum hourly biogas consumption $\left(D_{M}\right)$

$\mathrm{D}_{\mathrm{M}}=175 \times 4+120 \times 18=2860 \mathrm{l} / \mathrm{h}$

$\mathrm{D}_{\mathrm{M}}-\mathrm{Y}_{\mathrm{M}}=2860-830.83=2029.17 \mathrm{l} / \mathrm{h}$

The longest period of maximum biogas consumption is 3 hours

Hence, the necessary gasholder volume $\left(\mathrm{V}_{\mathrm{G1}}\right)$ during consumption is

$\mathrm{V}_{\mathrm{G} 1}=2029.17 \times 3=6087.511$ 8 AM.

The longest interval of zero-consumption is 11 hours from 9PM to

$\mathrm{V}_{\mathrm{G} 2}=830.83 \times 11=9139.131$

The larger volume $\left(\mathrm{V}_{\mathrm{G} 1}\right.$ or $\mathrm{V}_{\mathrm{G} 2}$ determines the size of the gasholder.

Allowing for the safety margin of $25 \%$, the gasholder volume $\left(\mathrm{V}_{\mathrm{G}}\right)$ is thus:

$\mathrm{V}_{\mathrm{G}}=9139.131 \times 1.25=11423.913751$

Scaling of digester: The amount of fermentation slurry $\left(Q_{B}\right)$ prepared from 2 cows and 13 rabbits.

$\mathrm{Q}_{\mathrm{C}}=12 \times 2=24 \mathrm{l} / \mathrm{d}$

$\mathrm{Q}_{\mathrm{R}}=1 \times 13=13 \mathrm{l} / \mathrm{d}$

$\mathrm{Q}_{\mathrm{B}}=\mathrm{Q}_{\mathrm{C}}+\mathrm{Q}_{\mathrm{R}}=37 \mathrm{l} / \mathrm{d}$

Daily amount of toilet water $\left(\mathrm{Q}_{\mathrm{S}}\right)$ produced by 421 persons.

Specific toilet wastewater production is 5 liters per person per day

$\mathrm{Q}_{\mathrm{S}}=5 \times 421=2105 \mathrm{l} / \mathrm{d}$

$\mathrm{Q}_{\mathrm{T}}=\mathrm{Q}_{\mathrm{B}}+\mathrm{Q}_{\mathrm{S}}=2142 \mathrm{l} / \mathrm{d}$

Chosen Hydraulic Retention Time (HRT) of 50 days

$\mathrm{V}_{\mathrm{s}}=2142 \times 50=1071001$

Volume total of digester $=$ Volume of gas + Volume of sludge

$$
=11423.91375+107100
$$

Therefore, $\mathrm{V}_{\mathrm{D}}=118523.9138 \mathrm{l}$

Radius of digester

$\mathrm{V}=2 \pi r^{3} / 3$ 
$118.52391381=2 \times 3.14 \times \mathrm{R}^{3} / 3$

$56.6197=\mathrm{R}^{3}$

$\mathrm{R}=3.84 \mathrm{~m}$

Radius of expansion chamber: The volume of the expansion chamber is equal to that of the volume of the gas in the main chamber, in order to allow for an excess of gas being produced without excessive pressure in the chamber.

$$
\begin{aligned}
& \mathrm{V}=2 \pi r^{3} / 3 \\
& 11.42391375=2 \times 3.14 \times \mathrm{R}^{3} / 3 \\
& 5.457283=\mathrm{R}^{3}
\end{aligned}
$$$$
\mathrm{R}=1.76 \mathrm{~m}
$$

The Table 2 shows the result obtained after data analysis and calculation. The size of the digester $\left(\mathrm{v}_{\mathrm{d}}\right)$ was determined as to be 118.524 $\mathrm{m}^{3}$ on the basis of the chosen retention time and daily substrate input quantity $\left(\mathrm{Q}_{\mathrm{t}}\right)$. For construction of this dome the radius of $3.8 \mathrm{~m}$ must be taken account and for further information for step of construction we refer to chapter 2.16. A common design for the compensation tank is to provide hemisphere with the similar radius of overflow tank as shown in Figure 3. The farmer could curtail additional raw manure and hold it steady at the two cows, 13 rabbits and 421 persons. If money is available and there are no digging problems, it is better to put in an oversized than undersized tank.

\section{Estimated carbonate biogas emission} [16]

$1 \mathrm{~m}^{3}$ of sludge $=22.5 \mathrm{~m}^{3}$ biogas $=146 \mathrm{kwh}$ gross $=36 \mathrm{~kg} \mathrm{CO}_{2}$ emission

With our designed biogas, volume of sludge $=107.1 \mathrm{~m}^{3}$

Total $\mathrm{CO}_{2}$ emitted by sludge $=107.1 \times 36=3855.6 \mathrm{~kg}$ of $\mathrm{CO}_{2}$ per day

$1 \mathrm{~m}^{3}$ biogas $=0.5 \mathrm{~L}$ fuel oil $=1.6 \mathrm{~kg}$ of $\mathrm{CO}_{2}[16]$

In our case, volume of gas production $=19.940 \mathrm{~m}^{3} / \mathrm{d}$
Carbonate biogas emission $=19.940 \times 1.6=31.904 \mathrm{~kg} \mathrm{CO}_{2}$ per day

$1 \mathrm{~m}^{3}$ biogas $=5.5 \mathrm{~kg}$ fire wood $=11 \mathrm{~kg} \mathrm{CO} \mathrm{CO}_{2}[16]$

$1 \mathrm{~kg}$ of fire wood $=11 / 5.5=2 \mathrm{~kg} \mathrm{CO}_{2}$

$19.940 \mathrm{~m}^{3} \rightarrow 5.5 \times 19.40=109.67 \mathrm{~kg}$ of fire wood $\rightarrow 2 \times 109.67=219.34$ $\mathrm{kg}$ of $\mathrm{CO}_{2}$ emitted by fire wood.

This indicate that the total carbonate biogas emitted is less than of that emitted by sludge and fire wood. Then biogas conserves the environment.

\section{Cost of fire wood}

Wood used per day to cook for 50 students $=1 / 2 \mathrm{~m}^{3}$ (obtained from field)

Cost of $1 \mathrm{~m}^{3}$ with transport=12.000 $\mathrm{rwf}$ (obtained from field)

Cost per day $=12000 \mathrm{rwf} / 2=6000 \mathrm{rwf}$

Cost for designed students per day $=7500 \times 421 / 50=63150 \mathrm{rwf} / \mathrm{d}$

The estimated cost of fire wood used per day by designed person was 63150 Rwandan francs.

Architectural design of fixed dome biogas plant at G.S. Ntarama (Figure 3)

\section{Estimated cost of biogas plant construction}

Plant capacity $=118.524 \mathrm{~m}^{3}$

Location: G.S. de Ntarama

As shown in Table 3, the estimated cost of a biogas of $118.524 \mathrm{~m}^{3}$ at G.S. Ntarama is $9860445 \mathrm{Rwf}$ according to Local prices have been considered for the local construction materials (stone, brick, sand, gravel) and labor. For the price of pipes and fittings the local market prices have been considered. For the prices of appliances gas stove the cost provided by EWSA and NDBP has considered as this is not available in the market. Cost of mason is kept as the local construction cost.

\section{Gashaki Sector}
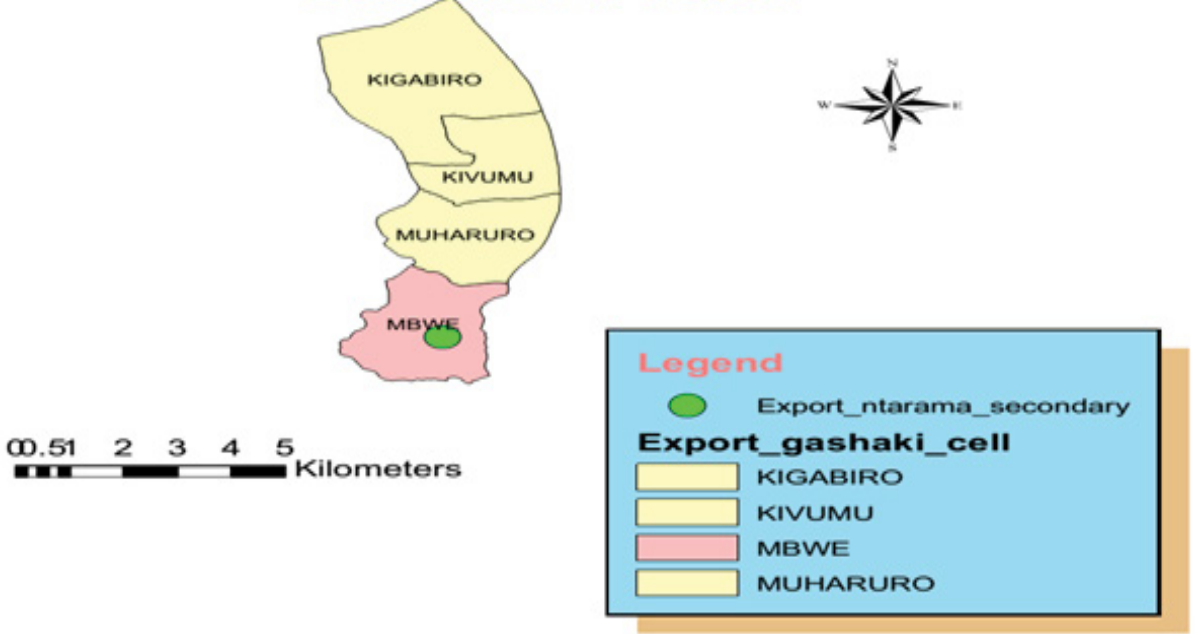

Figure 2: Location of G.S. Ntarama in Gashaki Sector. 
Citation: Kundwa MJ, Mahame C, Bigirimana T, Sanga P (2018) Contribution of Modern Biogas Plant to Energy Source and Environment Protection in Rwanda. J Civil Environ Eng 8: 325. doi: 10.4172/2165-784X.1000325

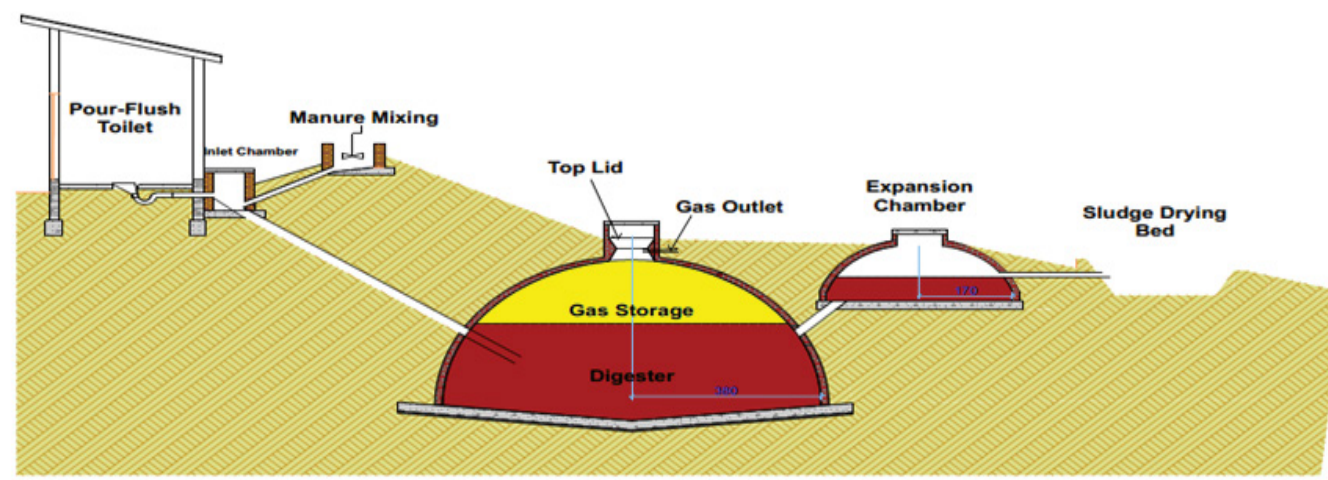

Figure 3: Biogas plant layout.

\begin{tabular}{|c|c|c|}
\hline Type of feeding materials & Daily production per producer (Kg) \\
\hline Cattle manure & $12 \mathrm{~kg}$ & Gas yield (L/Kg) \\
\hline Rabbits & 250 \\
\hline Human excreta & $0.5 \mathrm{~kg}$ \\
\hline
\end{tabular}

Table 1: Properties of feeding materials [14].

\begin{tabular}{|c|c|c|}
\hline Components & Plant size \\
\hline Digester volume & $118.524 \mathrm{~m}^{3}$ \\
\hline Gas volume & $11.42 \mathrm{~m}^{3}$ \\
\hline Digester radius & $3.8 \mathrm{~m}$ \\
\hline Expansion chamber radius & $1.7 \mathrm{~m}$ \\
\hline
\end{tabular}

Table 2: Designed elements of biogas plant.

\begin{tabular}{|c|c|c|c|c|}
\hline Work description & Unit & Quantity & Unit price (rwf) & Amount (rwf) \\
\hline \multicolumn{5}{|c|}{ Preliminary work } \\
\hline Site installation & LS & 1 & 120000 & 120000 \\
\hline Leveling & $\mathrm{m}^{3}$ & 180 & 2000 frw & 360000 \\
\hline Excavation & $\mathrm{m}^{3}$ & 255.46 & 2500 & 638650 \\
\hline \multicolumn{5}{|c|}{ Construction works } \\
\hline Blinding concrete & $\mathrm{m}^{3}$ & 3.87 & 30000 & 116100 \\
\hline Reinforced base slab & $\mathrm{m}^{3}$ & 18.75 & 100000 & 1875000 \\
\hline Dome wall in burnt bricks & $\mathrm{m}^{3}$ & 28.23 & 50000 & 1411500 \\
\hline Plastering & $\mathrm{m}^{2}$ & 492.6 & 10000 & 4926000 \\
\hline \multicolumn{5}{|c|}{ Pipe fittings and accessories } \\
\hline Inlet pipe & $\mathrm{m}$ & 6 & 1500 & 9000 \\
\hline Gas pipe & $\mathrm{m}$ & 25 & 1000 & 25000 \\
\hline Galvanized nipple Pipe 1/2" & pcs & 20 & 500 & 10000 \\
\hline PVC adapter socket 1/2" & pcs & 3 & 500 & 1500 \\
\hline Main gas valve & pcs & 2 & 1500 & 3000 \\
\hline Water trap & pcs & 1 & 1500 & 1500 \\
\hline Gas stove & pcs & 4 & 20000 & 80000 \\
\hline Biogas lamp & pcs & 18 & 15000 & 270000 \\
\hline Pressure gauge & pcs & 1 & 7000 & 7000 \\
\hline Gas tap & pcs & 1 & 2500 & 2500 \\
\hline \multicolumn{5}{|c|}{ Finishing works } \\
\hline Compacted fill & $\mathrm{m}^{3}$ & 107.13 & 1500 & 160695 \\
\hline Final work & LS & 1 & 200000 & 200000 \\
\hline \multicolumn{4}{|c|}{ Total } & 9860445 rwf \\
\hline
\end{tabular}

Table 3: Estimated cost of biogas plant construction.

\section{Conclusion}

The objective of this research was mainly to solve energy related problems in rural schools and problems endangering environment through the initiation of modern biogas. The size of plant digester volume was determined to be $118.524 \mathrm{~m}^{3}$. Basing on the findings of this project, the cost of construction of biogas is $9860445 \mathrm{rwf}$; the biogas was designed to operate under the need of 2 cattle, 13 rabbit and toilet water for a community of 421 humans. The produced energy have to satisfy dairy cooking during 3 hours and lighting during 4 hours. The fixed 
Citation: Kundwa MJ, Mahame C, Bigirimana T, Sanga P (2018) Contribution of Modern Biogas Plant to Energy Source and Environment Protection in Rwanda. J Civil Environ Eng 8: 325. doi: 10.4172/2165-784X.1000325

Page 7 of 7

dome biogas plant type was chosen because of low cost and cheaper technology. The Cost of biogas plant construction can cover the total cost of fire wood consumed in five months. Money spent on fertilizers will be saved. Biogas emits lesser carbon dioxide than firewood by seven times and it is environmental friendly. This study warrants the implementation of a biogas energy initiative as the major domestic energy for cooking and lighting. The research will be a good manual for any school located in rural area in Rwanda and will enhance living condition of students and surrounding people in general.

\section{Recommendations}

Biogas being cheap, reliable, easy to construct and sustainable; it is a necessary technology which needs exploration to benefit G.S. Ntarama and rural schools in general. There is a need to sensitize people and other institutional about the use of biogas as a cheap reliable source of energy and the Need to train biogas technicians as it is new initiative in Rwandan rural schools. Hence, recommendation goes to any other researchers in engineering field, or anyone else who wishes and who is capable to do further research in this field for the sake of executing this project. Government should come in to promote the use of biogas through financing of the construction at a community level or through initiating the creation of biogas loans and this can be a good supplement to the ongoing rural electrification program.

\section{References}

1. Owekisa D (2008) Financing domestic biogas in Rwanda. SNV-Rwanda, Kigali, Rwanda.

2. Samer M (2012) Biogas plant constructions. Biogas. London, IntechOpen, UK.

3. Membere AE, John U, Joshua O (2013) Computational model for biogas production from solid waste. Journal of Environment 2: 47-51.

4. Al-Seadi T, Rutz D, Prassl H, Köttner M, Finsterwalder T, et al. (2008) Biogas
Handbook. University of Southern, Denmark.Ocwieja SM (2010) Life cycle thinking assessment applied to three Biogas projects in central Uganda. Michigan Technology University, USA

5. Ocwieja SM (2010) Life cycle thinking assessment applied to three Biogas projects in central Uganda. Michigan Technology University, USA

6. Membere EA, Ugbebor J, Akan UE (2012) Biomechanization potential of organic fraction of municipal solid waste from co-digestion of pig and cow dung. International Journal of Environmental Science 2: 2387-2399.

7. Anicet MP (2008) Performance assessment of Institutional Biogas System in Rwanda Report. Kigali, Rwanda.

8. Kaur H, Kumar S (2017) Designing of small scale fixed dome biogas digester for paddy straw. IJRER 7: 422-431.

9. Molla A (2014) Design of cylindrical fixed dome bio digester in the condominium houses for cooking purpose at Dibiza Site, East Gojjam, Ethiopia. Am J Energy Eng 2: 19-22.

10. Amingun B, Parawira W, Musango JK, Aboyade AO, Badmos AS (2012) Anaerobic Biogas Generation for Rural area Energy Provision in Afrcica. Biogas. London, IntechOpen, UK.

11. Hiloidhari M, Das D, Baruah DC (2014) Bioenergy potential from crop residue biomass in India. Renew Sust Energ Rev 32: 504-512.

12. Joshi A, Bhatia M, Kumar P, Barua P, Mohan RR, et al. (2011) Biomass for sustainable development-Lessons for decentralized energy delivery-village energy security programme. South Asia Region, India Country Management Unit, Document of the World Bank.

13. Dumitri M (2014) Consideration over biogas plant components. Scientific Papers Series- Management, Economic Engineering in Agriculture and Rura Development 14: 121-126.

14. Macharia D, Musungu WN (2008) Institutional Biogas Plant Installer Manual. IT Power Eastern Africa, Woodvale Groove, Westlands, Kenya.

15. Ecosan Services Foundation (2007) Training materials on biogas sanitation. ESF.

16. Casada ME, Safley LM (1990) Global methane emissions from livestock and poultry manure. United States Environmental Protection Agency, USA. 